\title{
Comparative analysis of traditional and alternative energy in the Russian Federation
}

\author{
Dmitry Dvinin ${ }^{1 *}$, Ekaterina Nikolaeva ${ }^{1}$ \\ ${ }^{1}$ Chelyabinsk State University, 129 Kashirin Brothers Street, Chelyabinsk, 454001, Russia
}

\begin{abstract}
The study obtained the totals of material intensity (resource intensity) and greenhouse gas emissions for all regions of the Russian Federation with traditional and alternative energy sources. The share of alternative energy in the regional energy balance, the total amount of natural resources consumed as a result of its activities (expressed in total material input numbers). It has been established that the emission of greenhouse gases by the traditional electric power industry is 788.56 million tons. Greenhouse gas emissions from alternative power generation activities in the Russian Federation are relatively low, with emissions of 0.11 million tons, and are associated exclusively with the activities of biofuel plants. The volume of matter transported due to traditional energy activities in the Russian Federation is 2 billion tons. The volume of material transported due to alternative energy activities in the Russian Federation is minimal and amounts to 421 thousand tons. Even in a hypothetical scenario, when alternative electricity completely replaces traditional energy, the volume of transported material will be almost 7 times less than fossil fuel energy. Thus, the ecological and economic advantage of alternative energy development in the Russian Federation is established, which is expressed in significant resource saving.
\end{abstract}

\section{Introduction}

Material flows that exist in various sectors of the economy have a direct impact on the state of the natural environment. However, when dealing with environmental issues, the main focus is on regulating emissions to the environment, which is only a consequence of the material flows. An adequate assessment of the environmental and economic advantages and anthropogenic impact of alternative energy is possible only through an assessment of the material flows that arise as a result of its activities [1-3].

However, with existing methods of assessment, emissions into the environment are given the most attention, while forgetting to identify material flows. Besides, the assessment of material flows makes it possible to establish the relationship between the natural and socio-economic system, since the extracted natural resources have a market price, and to more adequately identify the cost of alternative energy. At the moment, there is a problem of estimating the consumed natural resources, since traditional and alternative energy uses different material incoming flows, a criterion is needed where all types of

\footnotetext{
*Corresponding author: dvinin1981@mail.ru
} 
consumed natural resources are reduced to a single value $[4,6]$.

The study suggests relying on the criterion proposed by the Wuppertal Institute for Climate and Environment (Germany): MI (material input) numbers [5]. They express the amount of various natural resources and environmental elements (in kilograms) required to produce $1 \mathrm{~kg}$ of primary material. Special attention is paid to ecological and economic assessment using a modified criterion of total MI numbers, which is the whole of all incoming ecosystem natural resources and elements. Using this criterion, it became possible to determine the environmental and economic advantages of the alternative power industry in Russia and identify new patterns of the energy industry through the level of its material intensity.

\section{Materials and Methods}

The resource intensity of alternative power generation facilities was based on materials obtained by the Wuppertal Institute of Climate and Environment, which provides specific indicators of resource intensity for various energy sources, taking into account the necessary costs for the production and operation of these facilities. The calculations were performed as follows: inventory analysis of "input" and "output" flows of natural resources was performed, then these flows were transferred to the category of total MI numbers [5-7].

For wind farms, the following specific indicators of resource intensity are obtained, expressed in MI numbers [5]: atmospheric resources, $\mathrm{kg} / \mathrm{kWh}-0.008$; abiotic resources, $\mathrm{kg} / \mathrm{kWh}-0.09$; water resources, $\mathrm{kg} / \mathrm{kWh}-0.84$; total MI numbers, $\mathrm{kg} / \mathrm{kWh}-0.1$.

For solar power plants [5]: atmospheric resources, $\mathrm{kg} / \mathrm{kWh}-0.0009$; abiotic resources, $\mathrm{kg} / \mathrm{kWh}-0.12$; water resources, $\mathrm{kg} / \mathrm{kWh}-4.93$; total MI numbers, $\mathrm{kg} / \mathrm{kWh}-0.12$.

Information on the amount of water consumed during power generation was used to identify the specific resource intensity of small hydroelectric power plants. Currently, there is no clear regulatory criterion for classifying a hydroelectric power plant as a small plant, however, in the previous SNiP 2.06.01-86 "Hydraulic Structures. The Main Design Provisions", small hydroelectric power plants included objects with an installed capacity of up to $30 \mathrm{MW}$. This value was taken as a basis in the study.

The final values for the region as a whole were calculated, taking into account the share of each power plant in the energy balance [9]. Since the study aimed to analyze the current level of anthropogenic impact, the categories of material inputs (abiotic and atmospheric resources) associated with greenhouse gas emissions were singled out separately. MI numbers were summed and combined to facilitate analysis in the total [10].

The assessment of greenhouse gas emissions was based on the IPCC (Intergovernmental Panel on Climate Change) methodology. According to the IPCC Guidelines, when conducting an assessment in the electric power industry, it is necessary to take into account the values associated with the combustion of various fuels; this category determines the specific coefficients of greenhouse gas emissions. Greenhouse gas emission is the following: carbon dioxide, nitrous oxide, methane, nitrogen trifluoride, and freon. However, due to the small volume of emissions of any gases other than carbon dioxide, to facilitate future analysis, it is proposed to express all emissions in the form of CO2-eq. (carbon dioxide equivalent).

\section{Results}

Based on the proposed methods, a comparative analysis of the resource intensity and level of greenhouse gas emissions of the traditional fossil fuel power industry and alternative 
power industry was carried out. The specific value of alternative energy of different genesis was also revealed: solar power plants, wind farms, geothermal power plants, small hydroelectric power plants, and biofuel power plants.

The study was carried out for all regions of the Russian Federation. The obtained results are presented in Table 1 .

Table 1. Greenhouse gas emissions and resource intensity of regional electric power complexes of the Russian Federation

\begin{tabular}{|c|c|c|c|c|c|c|}
\hline \multirow[b]{2}{*}{ Regions } & \multicolumn{3}{|c|}{ Traditional electric power industry } & \multicolumn{3}{|c|}{ Alternative power industry } \\
\hline & $\begin{array}{c}\text { Electricity } \\
\text { generation per } \\
\text { year million } \\
\text { kWh }\end{array}$ & $\begin{array}{c}\text { Resource } \\
\text { intensity } \\
\text { expressed in } \\
\text { total MI } \\
\text { numbers, } \\
\text { thousand tons }\end{array}$ & $\begin{array}{l}\text { Greenhouse } \\
\text { gas emissions, } \\
\text { thousand tons }\end{array}$ & $\begin{array}{c}\text { Electricity } \\
\text { generation per } \\
\text { year, mln kWh }\end{array}$ & $\begin{array}{c}\text { Resource } \\
\text { intensity } \\
\text { expressed in } \\
\text { total MI } \\
\text { numbers, } \\
\text { thousand } \\
\text { tons }\end{array}$ & $\begin{array}{c}\text { Greenhous } \\
\text { e gas } \\
\text { emissions } \\
\text { thousand } \\
\text { tons }\end{array}$ \\
\hline Northwestern Federal District & $\mathbf{9 7 , 9 6 9 . 3 2}$ & $61,720.67$ & $26,451.72$ & 204.05 & 0.51 & - \\
\hline Komi Republic & $8,974.09$ & $11,576.57$ & $6,012.64$ & 93.86 & - & - \\
\hline Republic of Karelia & $4,194.98$ & 964.84 & 503.4 & 0.005 & 0.0005 & - \\
\hline Pskov Region & 623.5 & 635.97 & 336.7 & 8 & - & - \\
\hline Novgorod Region & 540.18 & 696.83 & 340.31 & - & - & - \\
\hline Nenets Autonomous Area & 154.3 & 209.85 & 143.5 & 0.5 & 0.05 & - \\
\hline Murmansk Region & $15,978.71$ & $3,834.89$ & 479.36 & 71.39 & 0.085 & - \\
\hline Leningrad Region & $36,740.32$ & $13,593.91$ & $2,571.82$ & 0.22 & - & - \\
\hline Kaliningrad Region & $6,199.15$ & $4,773.34$ & $2,541.65$ & 15.07 & 0.37 & - \\
\hline Saint Petersburg & $16,238.31$ & $13,802.56$ & $7,307.24$ & 15 & - & - \\
\hline Vologda Region & $4,479.23$ & $6,674.05$ & $3,314.63$ & 0.001 & 0.0001 & - \\
\hline Arkhangelsk Region & $3,846.55$ & $4,731.25$ & $2,538.72$ & 93.86 & - & - \\
\hline Central Federal District & $222,487.6$ & $169,090.57$ & $68,971.15$ & 147.84 & 132.43 & 0.11 \\
\hline Yaroslavl Region & $3,620.45$ & $2,679.13$ & $1,448.18$ & 1.02 & - & - \\
\hline Tula Region & $3,996.57$ & $7,593.48$ & $3,956.6$ & - & - & - \\
\hline Tver Region & $44,394.48$ & $21,753.29$ & $5,771.28$ & 9.6 & & - \\
\hline Tambov Region & $1,054.13$ & $1,106.83$ & 590.31 & - & - & - \\
\hline Smolensk Region & $27,767.37$ & $11,384.62$ & $1,943.71$ & - & - & - \\
\hline Ryazan Region & $8,294.79$ & $22,644.77$ & $10,700.28$ & - & - & - \\
\hline Orel Region & $1,146.84$ & $1,020.69$ & 550.48 & 8 & - & - \\
\hline Moscow Region & $24,221.93$ & $29,066.32$ & $13,322.06$ & 99.76 & - & - \\
\hline Lipetsk Region & $1,751.59$ & $1,734.07$ & 928.34 & - & - & - \\
\hline Kursk Region & $31,160.19$ & $10,594.46$ & 623.2 & - & - & - \\
\hline Kostroma Region & $15,101.73$ & $14,195.62$ & $7,550.86$ & - & - & - \\
\hline Kaluga Region & 49.53 & 51.02 & 27.24 & - & - & - \\
\hline Ivanovo Region & $2,308.19$ & $2,331.27$ & $1,246.42$ & - & - & - \\
\hline Moscow & $41,046.24$ & $36,120.69$ & $19,291.73$ & - & - & - \\
\hline Voronezh Region & $14,169.4$ & $5,667.76$ & 850.16 & - & - & - \\
\hline Vladimir Region & $1,868.3$ & $1,774.88$ & 952.83 & - & - & - \\
\hline Bryansk Region & 17.08 & 23.06 & 12.3 & - & - & - \\
\hline Belgorod Region & 518.79 & 409.84 & 217.9 & 29.46 & 132.43 & 0.11 \\
\hline Southern Federal District & $63,125.76$ & $42,925.51$ & $19,568.9$ & 547.9 & 56.63 & - \\
\hline Rostov Region & $32,672.76$ & $25,158.02$ & $9,801.83$ & - & - & - \\
\hline Republic of Crimea and Sevastopol & $1,367.11$ & $1,223.67$ & 622.54 & 427.5 & 49.19 & - \\
\hline Republic of Kalmykia & 9 & 3.87 & 1.71 & - & - & - \\
\hline Republic of Adygea & 48.4 & 0 & 0 & 50.4 & - & - \\
\hline Krasnodar Region & $10,659.08$ & $9,486.58$ & $5,116.36$ & 8 & - & - \\
\hline Volgograd Region & $15,819.24$ & $4,429.39$ & $2,372.89$ & 62 & 7.44 & - \\
\hline Astrakhan Region & $2,550.17$ & $2,881.69$ & $1,555.6$ & - & - & - \\
\hline
\end{tabular}

Table 2. Greenhouse gas emissions and resource intensity of regional electric power complexes of the Russian Federation (continued)

\begin{tabular}{|c|c|c|c|c|c|c|}
\hline Regions & $\begin{array}{c}\text { Traditional } \\
\text { electric } \\
\text { power } \\
\text { industry }\end{array}$ & $\begin{array}{c}\text { Alternative } \\
\text { power } \\
\text { industry }\end{array}$ & $\mathbf{1 0 , 1 9 3 . 4 7}$ & $\mathbf{6 2 1 . 6}$ & $\mathbf{1 . 0 8}$ & $\mathbf{-}$ \\
\hline $\begin{array}{c}\text { Chechen Republic and the } \\
\text { Republic of Ingushetia }\end{array}$ & $\begin{array}{c}\text { Electricity } \\
\text { generation } \\
\text { per year }\end{array}$ & $\begin{array}{c}\text { Resource } \\
\text { intensity } \\
\text { expressed in }\end{array}$ & $\begin{array}{c}\text { Greenhouse } \\
\text { gas emissions, } \\
\text { thousand tons }\end{array}$ & $\begin{array}{c}\text { Electricity generation per } \\
\text { year, mln kWh }\end{array}$ & $\begin{array}{c}\text { Resource } \\
\text { intensity } \\
\text { expressed in }\end{array}$ & $\begin{array}{c}\text { Greenhouse } \\
\text { gas } \\
\text { emissions, }\end{array}$ \\
\hline
\end{tabular}




\begin{tabular}{|c|c|c|c|c|c|c|}
\hline & million $\mathrm{kWh}$ & $\begin{array}{c}\text { total MI } \\
\text { numbers, } \\
\text { thousand } \\
\text { tons }\end{array}$ & & & $\begin{array}{c}\text { total MI } \\
\text { numbers, } \\
\text { thousand tons }\end{array}$ & $\begin{array}{l}\text { thousand } \\
\text { tons }\end{array}$ \\
\hline Stavropol Krai & $19,008.8$ & $19,198.89$ & $10,264.75$ & 205 & - & - \\
\hline Republic of North Ossetia & 412.4 & 16.5 & 8.25 & 164.2 & - & - \\
\hline Republic of Dagestan & $5,470.53$ & 109.41 & 54.7 & 204 & 1.08 & - \\
\hline $\begin{array}{c}\text { Karachayevo-Circassian } \\
\text { Republic }\end{array}$ & $1,291.2$ & 0 & 0 & 17.4 & - & - \\
\hline $\begin{array}{c}\text { Kabardino-Balkarian } \\
\text { Republic }\end{array}$ & 626.5 & 0 & 0 & 15.5 & - & - \\
\hline Volga Federal District & $176,734.4$ & $134,318.14$ & $65,391.73$ & 221.31 & 22.58 & - \\
\hline Ulyanovsk Region & $2,758.32$ & $2,592.82$ & $1,379.16$ & 96 & 8.6 & - \\
\hline Saratov Region & $40,286.18$ & $14,503.02$ & $2,820.03$ & 0.11 & 0.013 & - \\
\hline Samara Region & $23,129.27$ & $13,646.27$ & $7,170.07$ & 5.5 & - & - \\
\hline Republic of Chuvashia & $4,928.71$ & $2,562.93$ & $1,330.75$ & - & - & - \\
\hline Republic of Udmurtia & $2,598.81$ & $2,364.91$ & $1,273.41$ & - & - & - \\
\hline Republic of Tatarstan & $21,646.93$ & $19,915.17$ & $10,606.99$ & 0.3 & - & - \\
\hline Republic of Mordovia & $1,116.81$ & $1,127.97$ & 603.07 & 0.35 & - & - \\
\hline Mari El Republic & 702.99 & 625.67 & 330.4 & - & - & - \\
\hline Republic of Bashkortostan & $18,839.51$ & $19,781.48$ & $9,796.54$ & 41.46 & 4.92 & - \\
\hline Perm Region & $30,463.45$ & $25,893.93$ & $14,013.19$ & 0.35 & - & - \\
\hline Penza Region & $1,517.87$ & $1,457.15$ & 774.11 & 0.2 & - & - \\
\hline Orenburg Region & $14,639.56$ & $14,639.56$ & $7,758.97$ & 75.34 & 9.05 & - \\
\hline Nizhny Novgorod Region & $9,370.02$ & $8,151.91$ & $4,310.21$ & - & - & - \\
\hline Kirov Region & $4,735.96$ & $7,435.45$ & $3,267.81$ & 1.7 & - & - \\
\hline Ural Federal District & 129,678 & $172,471.74$ & $73,916.46$ & 35.8 & 0.054 & - \\
\hline $\begin{array}{l}\text { Yamalo-Nenets Autonomous } \\
\text { District }\end{array}$ & 1,201 & 996.83 & 576.48 & 0.54 & 0.054 & - \\
\hline Chelyabinsk Region & $23,700.8$ & $42,898.45$ & $20,619.67$ & 1.5 & - & - \\
\hline $\begin{array}{l}\text { Khanty-Mansi Autonomous } \\
\text { District }\end{array}$ & 77,505 & $91,455.9$ & $37,977.45$ & - & - & - \\
\hline Tyumen Region & $11,906.3$ & $14,525.68$ & $5,834.09$ & - & - & - \\
\hline Sverdlovsk Region & $15,364.9$ & $25,198.43$ & $11,677.32$ & 33.76 & - & - \\
\hline Kurgan Region & $3,103.4$ & $4,096.48$ & $1,799.97$ & - & - & - \\
\hline Siberian Federal District & $186,506.7$ & $258,819.26$ & $91,388.28$ & $1,357.52$ & 160.78 & - \\
\hline Tomsk Region & 4,229 & $7,231.59$ & $3,256.33$ & 3 & 0.002 & - \\
\hline Republic of Khakassia & 22,600 & 7,458 & 1,808 & 6.5 & 0.78 & - \\
\hline Republic of Tuva & 67.2 & 86.68 & 33.6 & - & - & - \\
\hline Republic of Altai & 1,333 & 159.96 & 0 & 1,333 & 160 & - \\
\hline Omsk Region & $6,237.4$ & $13,971.77$ & $5,551.28$ & - & - & - \\
\hline Novosibirsk Region & $13,258.8$ & $18,297.14$ & $9,413.75$ & - & - & - \\
\hline Krasnoyarsk Territory & 52,302 & $104,080.98$ & $24,581.94$ & 15 & - & - \\
\hline Kemerovo Region & 21,392 & $43,853.6$ & $22,461.6$ & 0.020 & 0.002 & - \\
\hline Irkutsk Region & $59,364.8$ & $45,710.89$ & $10,685.66$ & - & - & - \\
\hline Altai Territory & $5,722.5$ & $17,968.65$ & $7,210.35$ & - & - & - \\
\hline $\begin{array}{c}\text { Far Eastern Federal } \\
\text { District }\end{array}$ & $56,783.46$ & $122,573.2$ & $30,663.07$ & $628,291.66$ & 47.8 & - \\
\hline Republic of Buryatia & $5,164.8$ & $23,189.95$ & $5,629.63$ & 14.54 & 1.7 & - \\
\hline Republic of Sakha (Yakutia) & $9,295.81$ & $9,574.68$ & $5,112.69$ & 437.12 & 0.05 & - \\
\hline Chukotka Autonomous Area & 475.6 & $1,084.37$ & 389.99 & 200 & 0.02 & - \\
\hline $\begin{array}{l}\text { Khabarovsk Territory with } \\
\text { the Jewish Autonomous } \\
\text { Region }\end{array}$ & $7,224.95$ & $14,305.4$ & $5,707.71$ & - & - & - \\
\hline Sakhalin Region & $2,085.2$ & $3,211.21$ & $1,563.9$ & 8541 & 0.85 & - \\
\hline Trans-Baikal Territory & $5,666.3$ & $27,764.87$ & $6,119.6$ & 199 & 0.001 & - \\
\hline Primorye Territory & $8,856.6$ & $35,603.53$ & $9,742.26$ & - & - & - \\
\hline Magadan Region & $2,563.5$ & 615.24 & 307.62 & - & - & - \\
\hline Kamchatka Territory & $1,702.7$ & $1,174.86$ & 629.99 & 618,900 & 45.18 & - \\
\hline Amur Region & 13,748 & $6,049.12$ & $1,374.8$ & - & - & - \\
\hline Russian Federation & $1,923,323.73$ & $2,000,256.68$ & $788,562.73$ & 2763.49 & 421.39 & 0.11 \\
\hline
\end{tabular}

Based on the calculations, the total resource capacity of the Russian fossil fuel electric power is about 2 billion tons (in MI numbers), the cost of alternative power is significantly less -0.42 million tons (in MI numbers). Greenhouse gas emission due to the activities of the traditional power industry of the Russian Federation is 788.56 million tons, and the emission resulting from the operation of alternative energy is 0.11 million tons. 


\section{Conclusions}

The calculations made it possible to identify the total volume of biosphere substance used in the activities of the traditional electric power industry of the Russian Federation's economy: 2 billion tons. This is 6.5 times more than the volume of river flow carried out by Russian rivers. The value is comparable to the flow of all terrestrial rivers. Substance mass necessary for the functioning of the electricity sector in Russia coincides with the volume of some natural geological forces, which fully confirms the concept of the Anthropocene, a new geologic epoch where human activity plays a leading role in the functioning of the biosphere.

The volume of biosphere matter transported by alternative power generation in the Russian Federation is insignificant: 0.42 million tons.

Even if the alternative power industry completely replaces the traditional energy industry, the volume of transported material will be about 300 million tons, which will be almost 7 times less than fossil fuel energy. Thus, it is possible to establish the ecological and economic advantage of alternative energy development in the Russian Federation, which is expressed in significant resource saving.

The volume of greenhouse gas emissions from the traditional electric power industry is 788.56 million tons; the highest values are in regions with developed coal energy: the Siberian Federal District (91.39 million tons) and Ural Federal District (73.91 million tons). A reasonably high relationship between resource intensity expressed by total MI numbers and the volume of greenhouse gas emissions was revealed: the correlation ratio is 0.998 .

As a result of the study, it was found that there are virtually no greenhouse gas emissions from alternative energy activities in the Russian Federation. Emissions amount to 0.11 million tons and are associated exclusively with the biofuel plant activities. This value is more than 7,000 times less than the volume of emissions from fossil fuel energy, and even if traditional energy is entirely replaced by alternative energy, where bioenergetics will also be present, the emission will be 10 times less. There is a small correlation between resource intensity and greenhouse gas emissions and alternative energy: the correlation ratio is 0.592 .

The reported study was funded by RFBR, project number 20-010-00195.

\section{References}

1. S. Giljum, Resources, Conservation and Recycling, 55, 300-308 (2011). DOI: 10.1016/j.resconrec.2010.09.009

2. G. Huppes, M. Ishikawa, Ecological Economics, 68, 1687-1700 (2009). DOI: 10.1016/j.ecolecon.2009.01.007

3. S. Sangwon, Ecological Modelling, 189, 251-269 (2005). DOI: 10.1016/j.ecolmodel.2006.01.002

4. F. Schiller. Ecological economics, 68, 1676-1686 (2009). DOI: 10.1016/j.ecolecon.2008.08.017

5. M. Ritthoff, H. Rohn, C. Liedtke, Wuppertal Spezial 27e; Wuppertal Institute for Climate, Environment and Energy: (Wuppertal, Germany, 2002) DOI: 10.3390/resources2040581

6. M. Dittrich, S. Bringezu, Ecological Economics, 69, 1838-1847 (2010) DOI: 10.1016/j.ecolecon.2010.04.023 
7. S.Salaa, B.Ciuffob, P. Nijkamp, Ecological Economics, 119, 314-325 (2015) DOI: 10.1016/j.ecolecon.2015.09.015

8. A. Padilla-Rivera, J. M. Morgan-Sagastume, L. P. Guereca-Hernandez Journal of Environmental Protection 10, 241-259. (2019) DOI: 10.4236/jep.2019.102014

9. I.S. Belik, N.V. Starodubec, A.I. Yachmeneva, Economy of Region, 4, 1211-1219 (2017) DOI: 10.17059/2017-4-19

10. A.Y. Davankov, D.Y. Dvinin, Y.A. Postnikov, Economy of Region, 4, 1029-1039 (2016) DOI: $10.17059 / 2016-4-5$ 